Jurnal Ilmiah Ibnu Sina, 6(2), Oktober 2021, 272-281

p-ISSN: 2502-647X; e-ISSN: 2503-1902

\title{
UJI TOKSISITAS AKUT EKSTRAK ETANOL DAUN KAYU MANIS (Cinnamomum burmanii) PADA FUNGSI HATI TIKUS PUTIH (Mus musculus L.) BETINA
}

\author{
Yesi Nursofia, Fathnur Sani K*, Yuliawati \\ Jurusan Farmasi, Universitas Jambi \\ *Email: fathnursanik@unja.ac.id
}

Artikel diterima: 18 Agustus 2021; Disetujui: 28 September 2021

DOI: https://doi.org/10.36387/jiis.v6i2.720

\begin{abstract}
ABSTRAK
Daun kayu manis (Cinnamomum burmanii) merupakan tanaman yang memiliki banyak efek farmakologis di antaranya sebagai penurun kadar gula darah, penghambat pertumbuhan bakteri, antioksidan dan aktivitas insulin mimetik. Namun, belum dilakukan pengujian toksisitas akut pada daun kayu manis sebelumnya. Penelitian ini bertujuan untuk mengetahui tingkat toksisitas dan pengaruh pemberian ekstrak terhadap SGOT, SGPT serta perubahan bentuk histopatologi hati hewan uji. Penelitian ini menggunakan metode Rancangan Acak Lengkap dengan 5 kelompok perlakuan dengan pemberian Na-CMC 0,5\% sebagai kontrol negatif, P1 dosis $250 \mathrm{mg} / \mathrm{kgBB}$, P2 Dosis $500 \mathrm{mg} / \mathrm{kgBB}$, P3 dosis 1000 $\mathrm{mg} / \mathrm{kgBB}$ dan $\mathrm{P} 4$ dengan dosis $2000 \mathrm{mg} / \mathrm{kgBB}$. Setiap perlakuan terdiri dari 5 mencit. Parameter yang diamati pada penelitian ini yaitu SGPT, SGOT dan pemeriksaan histopatologi organ hati mencit. Data dianalisis menggunakan uji One Way ANOVA dengan uji lanjut duncan. Hasil penelitan menunjukkan pemberian ekstrak etanol daun kayu manis tidak menimbulkan kematian pada hewan uji sehingga tergolong praktis tidak toksik. Nilai SGPT dan SGOT pada hewan uji mencit putih betina menunjukkan adanya perbedaan nilai SGPT dan SGOT yang bermakna secara statistik $(\mathrm{p}<0,05)$ dibandingkan dengan kontrol negatif. Namun, masih berada pada rentang normal. Hasil pengamatan histopatologi yakni terjadi perubahan hepatosit organ hati dibandingkan dengan kontrol negatif.
\end{abstract}

Kata kunci: Daun Kayu Manis, Toksisitas Akut, SGPT, SGOT, Histopatologi.

\begin{abstract}
Cinnamon leaves (Cinnamomum burmanii) are plants that have many pharmacological effects including lowering blood sugar levels, inhibition of bacterial growth, antioxidants and mymetic insulin activity. However, acute toxicity testing has not been carried out on cinnamon leaves before. This study aims to determine the level of toxicity and effect of extract administration on SGOT, SGPT as well as changes in the histopathological form of the liver of test animals. This study used The Complete Randomized Design method with 5 treatment groups with na-CMC administration $0.5 \%$ as a negative control, P1
\end{abstract}


Jurnal Ilmiah Ibnu Sina, 6(2), Oktober 2021, 272-281

p-ISSN: 2502-647X; e-ISSN: 2503-1902

dose $250 \mathrm{mg} / \mathrm{kgBB}$, P2 Dose $500 \mathrm{mg} / \mathrm{kgBB}, \mathrm{P3}$ dose $1000 \mathrm{mg} / \mathrm{kgBB}$ and P4 at a dose of $2000 \mathrm{mg} / \mathrm{kgBB}$. Each treatment consists of 5 mice. The parameters observed in this study are SGPT, SGOT and histopathological examination of mice liver organs. The data was analyzed using the One Way ANOVA test with duncan's advanced test. The results showed that the administration of cinnamon leaf ethanol extract did not cause death in test animals so it was practically not toxic. SGPT and SGOT values in female white mice test animals showed statistically meaningful differences in SGPT and SGOT values ( $p<0.05)$ compared to negative controls. However, it is still in the normal range. The result of histopathological observations is that there is a change in hepatocytes of liver organs compared to negative control.

Keywords: Cinnamon leaves, Acute toxicity test, SGPT, SGOT, histopathology

\section{PENDAHULUAN}

Provisi Jambi dikenal sebagai daerah unggulan penghasil kayu manis di karenakan memiliki Kabupaten pengembang kayu manis terluas di Indonesia, penyumbang utama produksi kayu manis nasional bersama Sumatera Barat dengan jumlah areal penanaman kayu manis di Kabupaten Kerinci seluas 40.962 ha (Nurhayati dan Rosmeli, 2019).

Daun kayu manis mengandung zat aktif tannin, eugenol, safrole, kalsium oksalat, damar, saponin, zat penyamak, dan sinnamaldehid (Rolini et al., 2015). Berdasarkan penelitian sebelumnya daun kayu manis memiliki khasiat sebagai penurun kadar gula darah (Kondoy et al., 2013), penghambat pertumbuhan bakteri (Qomar et al., 2018).

Salah satu parameter awal utuk mengevaluasi keamanan suatu obat yang akan di impelementasikan untuk tujuan pengembangan dan pemanfaatan kedepannya. Oleh karena itu, sangat diperlukan informasi yang menyampaikan batas aman penggunaan daun kayu manis (Makiyah et al., 2017).

Uji toksisitas akut oral berfungsi untuk mendeteksi efek toksik yang muncul dalam waktu singkat setelah pemberian sediaan uji yang diberikan secara oral dalam dosis tunggal yang diberikan dalam waktu 24 jam (Priyanto, 2010).

Pengujian LD L, SGPT dan SGOT serta pengamatan histologi bertujuan untuk mengetahui tingkat toksisitas bahan alami. Penentuan nilai $\mathrm{LD}_{50}$, SGPT dan SGOT ekstrak daun kayu manis (Cinnamomum burmanii) belum pernah dilakukan, 
Jurnal Ilmiah Ibnu Sina, 6(2), Oktober 2021, 272-281

p-ISSN: 2502-647X; e-ISSN: 2503-1902

sehingga perlu dilakukan pengujian pada ekstrak daun kayu manisterhadap mencit putih (Mus musculus $\mathrm{L}$.) betina.

\section{METODE PENELITIAN}

Alat

Mikrotom, fotometer Bts 350 biosystem, erlenmeyer, gelas beaker, stopwatch, botol maserasi, corong kaca, kertas saring, rotary evaporator, batang pengaduk, timbangan, kandang hewan uji, sonde oral, spuit, tempat pakan dan minuman hewan uji, mikroskop.

\section{Bahan}

Daun kayu manis, etanol 70\%, $\mathrm{Na}-\mathrm{CMC}$, aquadest, pereaksi mayer, wagner dan dragendoff, serbuk $\mathrm{Mg}$, $\mathrm{HCl}$ pekat, $\mathrm{HCl} 2 \mathrm{~N}$, etanol 96\%, kloroform, asam asetat anhidrat, asam sulfat pekat, methanol, nheksan, dietil eter, $\mathrm{NaOH}, \mathrm{NaCl}$ fisiologis $0,9 \%$, xylol, formalin, parafin, heparin, haemotoksilin eosin. Reagen A (Tris, L-alanine, lactate dehydrogenase), reagen $\mathrm{B}$ (NADH, 2-oxoglutarate, hodium hidroxide, sodium azide dan mencit putih betina.

\section{PROSEDUR PENELITIAN}

\section{Pengambilan Sampel}

Sampel yang digunakan adalah daun kayu manis (Cinnamomum burmanii) bagian yang diambil adalah daunnya yang segar yang didapatkan di Desa Ujung Ladang Kecamatan Gunung Kerinci, Kabupaten Kerinci Provinsi Jambi.

\section{Determinasi Tumbuhan}

Determinasi sampel daun kayu manis (Cinnamomum burmanii) dilakukan di Herbarium Jurusan Biologi FMIPA Universitas Andalas Padang, Sumatera Barat.

\section{Pembuatan Ekstrak Daun}

\section{Kayu Manis}

Metode yang digunakan yaitu metode maserasi menggunakan etanol $70 \%$. Serbuk direndam dalam 10 bagian pelarut selama 6 jam pertama sambil sesekali diaduk, kemudian diamkan selama 18 jam. Hasil maserat yang diperoleh difiltrasi, dan dilanjutkan remaserasi. Maserat yang sudah dikumpulkan di uapkan dengan alat rotary evaporator.

\section{Penentuan LDso Ekstrak}

Hewan uji yang telah di kelompokkan diberikan pensuspensi 
Jurnal Ilmiah Ibnu Sina, 6(2), Oktober 2021, 272-281

p-ISSN: 2502-647X; e-ISSN: 2503-1902

dan ekstrak secara peroral dengan dosis tunggal yang telah ditentukan. Volume pemberian $1 \%$ dari berat badan mencit. Perhitungan nilai $\mathrm{LD}_{50}$ didasarkan pada jumlah mencit yang mati pada setiap kelompok perlakuan selama rentang waktu 14 hari. Hasil yang diperoleh berupa deskripsi setiap efek toksik sebelum dan sesudah pemberian ekstrak (Priyanto, 2010).

\section{Pembuatan Larutan Koloidal Na-Cmc 0,5 \%}

$100 \mathrm{ml}$ aquadest dipanaskan dengan suhu $70^{\circ} \mathrm{C}$ NaCMC 0,5 gr dimasukkan sedikit demi sedikit sambil diaduk hingga terbentuknya larutan koloid yang homogen, kemudian volumenya dicukupkan dengan air panas sampai volume 100 ml (Adani et al., 2019).

\section{Pengelompokan}

Hewan

\section{Percobaan}

Sebelum diberi perlakuan masing-masing mencit ditimbang lalu mencit dibagi menjadi 5 kelompok. Masing-masing kelompok terdiri dari 5 ekor mencit, dengan perlakuan sebagai berikut:

a. Kontrol negatif (K-) : suspensi Na-CMC 0,5\% b. Perlakuan 1 (P1) : ekstrak daun kayu manis $250 \mathrm{mg} / \mathrm{kgBB}$

c. Perlakuan 2 (P2) : ekstrak daun kayu manis $500 \mathrm{mg} / \mathrm{kgBB}$.

d. Perlakuan 3 (P3) : ekstrak daun kayu manis $1000 \mathrm{mg} / \mathrm{kgBB}$

e. Perlakuan 4 (P4) : ekstrak daun kayu manis $2000 \mathrm{mg} / \mathrm{kgBB}$.

\section{Penentuan Nilai SGPT Dan SGOT}

Penentuan nilai SGPT dan SGOT menggunakan metode fotometri, sebanyak $250 \mu \mathrm{L}$ mono reagen SGPT/SGOT ditambahkan dengan $25 \mu \mathrm{L}$ serum sampel, diaduk hingga homogen dan didiamkan selama 50 detik, kemudian larutan diukur menggunakan alat fotometer portable Microlab 300 LX (Jumain et al., 2018).

\section{Pemeriksaan Histopatologi} Organ Hati Mencit

Organ dicuci menggunakan $\mathrm{NaCl} 0,9 \%$, dilakukan fiksasi menggunakan larutan formalin $10 \%$, didehidrasi menggunakan alkohol bertingkat dengan konsentrasi 70, 80, 90 dan 95\% masing-masing selama 24 jam dan dilanjutkan dengan alkohol $100 \%$ selama satu jam serta dilakukan pengulangan tiga kali, 
Jurnal Ilmiah Ibnu Sina, 6(2), Oktober 2021, 272-281

p-ISSN: 2502-647X; e-ISSN: 2503-1902

penjernihan menggunakan xilol tiga kali selama satu jam kemudian diinfiltrasi dengan parafin (Rahayu et al., 2018).

Organ ditanam dalam media parafin dan dilakukan penyayatan jaringan dengan ketebalan 4-5 mikron dan dilakukan pewarnaan menggunakan pewarna Hematoksilin Eosin (HE) yang selanjutnya diamati dengan mikroskop fluorescence (BPOM, 2014).

\section{Analisis Data}

Data yang diperoleh pada penelitian ini dianalisis dengan ANOVA satu arah menggunakan SPSS tingkat kepercayaan 95\%.

\section{HASIL DAN PEMBAHASAN}

\section{Hasil Determinasi Tumbuhan}

Hasil determinasi menunjukkan tumbuhan merupakan kelompok keluarga Lauraceae dan Spesies Cinnamomum burmanni (Nees \& T.Nees) Blume dengan nomor surat

158/KID/ANDA/III/2021.

2. Skrining Fitokimia Ekstrak Etanol Daun Kayu Manis

Hasil yang diperoleh sesuai dengan penelitian sebelumnya bahwa pada tumbuhan Kayu manis terkandung didalamnya alkaloid, flavonoid, tannin, saponin dan terpenoid (Rolini et al., 2015).

Tabel 1.Hasil Skrining Fitokimia

\begin{tabular}{ccc}
\hline No. & Pengamatan & Hasil \\
\hline 1. & Alkaloid & + \\
2. & Flavonoid & + \\
3. & Saponin & + \\
4. & Tanin & + \\
5. & Terpenoid & + \\
6. & Fenol & + \\
\hline
\end{tabular}

\section{Penentuan Nilai LD $_{50}$}

Metode ini menggunakan daftar perhitungan $\mathrm{LD}_{50}$ sehingga hasil yang diperoleh lebih akurat. Berdasarkan hasil yang diperoleh, pemberian sediaan tunggal dari $250 \mathrm{mg} / \mathrm{Kg} \mathrm{BB}, 500 \mathrm{mg} / \mathrm{Kg} \mathrm{BB}, 1500$ $\mathrm{mg} / \mathrm{Kg} \quad \mathrm{BB}$ secara peroral pada mencit hingga dosis maksimal 2000 $\mathrm{mg} / \mathrm{Kg}$ BB tidak menimbulkan kematian. Pada metode EOCD dosis 2000 merupakan dosis teratas (limit dose). Sehingga, dapat dikatakan bahwa ekstrak etanol daun kayu manis memiliki nilai $\mathrm{LD}_{50}$ lebih dari $2000 \mathrm{mg} / \mathrm{kgBB}$, yang menurut kategori GHS (Globally Harmonised Classification System for Chemical Substances and mixtures) yang tercantum dalam Thirteent Addendum to The OECD Guidelines 
Jurnal Ilmiah Ibnu Sina, 6(2), Oktober 2021, 272-281

p-ISSN: 2502-647X; e-ISSN: 2503-1902

for The Testing of Chemicals 2001 dosis tersebut termasuk dalam kategori 5 yang memiliki tingkat toksisitas yang rendah.

\section{Nilai Kadar SGPT Dan SGOT}

Efek toksik obat-obatan ataupun herbal berdampak pada hati karena hati berperan penting dalam mendetoksifikasi senyawa yang masuk ke dalam tubuh. Hepatotoksik dapat terjadi disebabkan adanya penumpukan xenobiotika pada hepar yang diekskresi melalui empedu sehingga terlihat pada kadar enzim SGOT dan SGPT pada hewan uji.

Adanya peningkatan aktivitas enzim SGOT dan SGPT menjadi indikator yang kuat dan peka terhadap kelainan pada sel-sel hati. Selain itu, perbedaan konsentrasi ekstrak yang diberikan dengan intenitas pemberian yang berbeda juga dapat berpengaruh terhadap kondisi morfologi hati (Wulandari et al., 2007).

Tabel 2. Kadar SGPT dan SGOT Serum Darah Mencit

\begin{tabular}{cccccc}
\hline No & Kelompok & $\begin{array}{c}\text { Rata-rata Kadar } \\
\text { SGPT (U/I) } \pm \text { SEM }\end{array}$ & $\begin{array}{c}\text { Rujukan } \\
\text { SGPT (U/I) }\end{array}$ & $\begin{array}{c}\text { Rata-rata Kadar } \\
\text { SGOT (U/I) } \pm \text { SEM }\end{array}$ & $\begin{array}{c}\text { Rujukan } \\
\text { SGOT (U/I) }\end{array}$ \\
\hline 1. & K- & $34^{\mathrm{a}} \pm 3,225$ & & $20^{\mathrm{a}} \pm 2,449$ & \\
2. & P1 & $40^{\mathrm{a}} \pm 6,753$ & & $30,4^{\mathrm{a}, \mathrm{b}} \pm 2,482$ & \\
3. & P2 & $52,4^{\mathrm{a}} \pm 7,040$ & $76-208$ & $40,6^{\mathrm{a}, \mathrm{b}} \pm 5,202$ & $30-314$ \\
4. & P3 & $52,4^{\mathrm{a}} \pm 8,846$ & & $31,8^{\mathrm{b}} \pm 3,693$ & \\
5. & P4 & $122,4^{\mathrm{b}} \pm 16,394$ & & $96,6^{\mathrm{c}} \pm 10,172$ & \\
\hline
\end{tabular}

a. Superskrip dengan huruf kecil yang berbeda pada baris yang sama menunjukkan perbedaan yang nyata $(\mathrm{p}<0,05)$.

b. $\mathrm{K}-=\mathrm{Na}-\mathrm{CMC} 0,5 \% ; \mathrm{P} 1=$ Ekstrak etanol daun kayu manis $250 \mathrm{mg} / \mathrm{kgBB} ; \mathrm{P} 2=$ Ekstrak etanol daun kayu manis 500 $\mathrm{mg} / \mathrm{kgBB}$; P3 = Ekstrak etanol daun kayu manis $1000 \mathrm{mg} / \mathrm{kgBB}$; P4 = Ekstrak etanol daun kayu manis $2000 \mathrm{mg} / \mathrm{kgBB}$.

Hasil uji Anova pada SGPT untuk semua kelompok diperoleh nilai sig $\mathrm{p}<0,05$ membuktikan bahwa terdapat perbedaan bermakna antara kelompok kontrol dan perlakuan. Hasil uji Anova pada SGOT untuk kontrol dan semua perlakuan diperoleh nilai sig $\mathrm{p}<0,05$ membuktikan bahwa terdapat
perbedaan bermakna antara
kelompok kontrol dan perlakuan.

Nilai normal untuk mencit yaitu 76-208 U/L untuk SGPT dan 30-314 U/I untuk SGOT (Nugraha et al., 2008). Dapat disimpulkan data nilai SGPT dan SGPT organ hati 
Jurnal Ilmiah Ibnu Sina, 6(2), Oktober 2021, 272-281

p-ISSN: 2502-647X; e-ISSN: 2503-1902

mencit disetiap perlakuan tergolong dalam kategori normal.

\section{Hasil Histopatologi Organ Hati}

Perubahan struktur histologis hati ini dipengaruhi oleh jumlah dan jenis senyawa yang masuk ke dalam organ hati, termasuk pemberian ekstrak etanol daun kayu manis, hasil pemeriksaan histopatologi hati mencit (Mus musculus) setelah diberikan perlakuan kontrol dan ekstrak etanol daun kayu manis mengalami perubahan struktur mikroanatomi pada sel hepatosit (Wulandari et al., 2007).

Sel hepatosit merupakan sel polygonal dengan membran yang jelas. Nukleus pada hepatosit menunjukkan variasi bentuk dan ukuran, beberapa kasus berbentuk binuklat dan kerusakan pada hati akibat zat beracun disebabkan oleh beberapa faktor diantaranya jenis yang terlibat, besarnya dosis yang diberikan serta lama paparan zat (Hasana et al., 2019).

Ditemukan perubahan sel hepatosit dari kontrol negatif yaitu degenerasi parenkim, degenerasi hidropik serta degenerasi lemak
(Abrori et al., 2019). Pemberian NaCMC $0,5 \%$ tidak menyebabkan kerusakan pada organ hati sesuai dengan penelitian histopatologi menunjukkan bentuk hepatosit yang normal (Utomo et al., 2012).

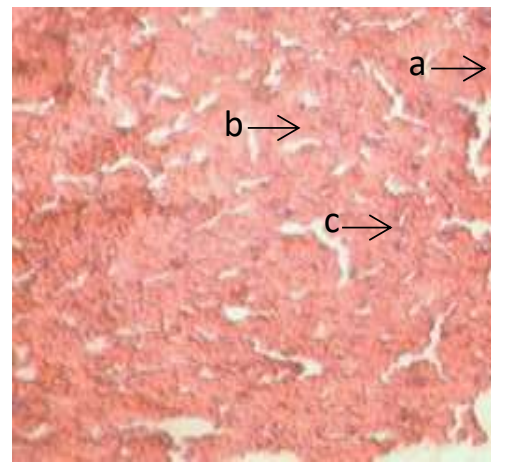

Gambar 1. Pemberian larutan $\mathrm{Na}-\mathrm{CMC}$ 0,5\%. Perbesaran 100x. Keterangan: a. hepatosit normal b. inti hepatosit c. hepatosit binukleat.

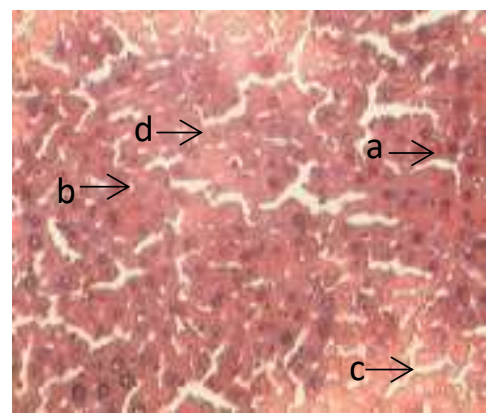

Gambar 2. Pemberian ekstrak etanol daun kayu manis 250 $\mathrm{mg} / \mathrm{kgBB}$. Perbesaran 100x.

Keterangan: a. Hepatosit normal b. Hepatosit binukleat $\mathrm{c}$. degenerasi parenkim $\mathrm{d}$. degenerasi lemak

Histopatologi hati kelompok P1 (Gambar 2) menunjukkan sel hepatosit terlihat normal, didapatkan jenis inti sel binukleat, ditemukan 
Jurnal Ilmiah Ibnu Sina, 6(2), Oktober 2021, 272-281

p-ISSN: 2502-647X; e-ISSN: 2503-1902

degenerasi parenkim dan degenerasi lemak. Jumlah degenerasi lemak yang terjadi lebih banyak ditemukan dibandingkan dengan kontrol negatif.

Gambaran histopatologi hati pada kelompok P2 (Gambar 3) ditemukan banyak degenerasi parenkim, ditemukan granula pada sitoplasma, membran sel tampak pudar sehingga jelas terlihat jenis inti sel binukleat. Degenerasi parenkim merupakan degenerasi paling ringan dimana terjadi pembengkakan dan kekeruhan sitoplasma. Pada perlakuan etanol $500 \mathrm{mg} / \mathrm{kgBB}$ membran sel tampak pudar dibandingkan kontrol negatif dan P1.

Pemberian ekstrak etanol daun kayu manis $1000 \mathrm{mg} / \mathrm{kgBB}$ terjadi degenerasi hidropik, dan jumlah degenerasi lemak yang lebih banyak dibandingkan dengan kelompok Kontrol negatif, P1 dan P2. Degenerasi hidropik merupakan derajat kerusakan yang lebih beratdibanding degenerasi lemak, perubahan ini terjadi akibat gangguan metabolisme seperti hipoksia atau keracunan bahan kimia (Utomo et al., 2012).

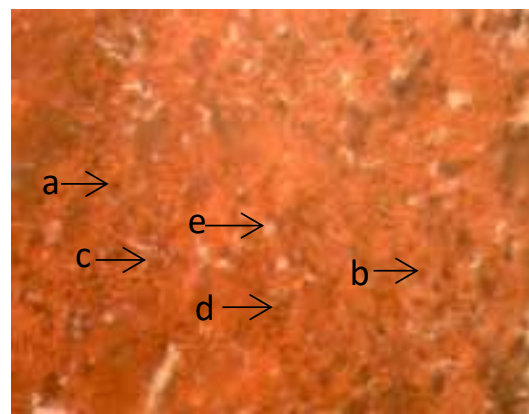

Gambar 3. Pemberian ektrak etanol daun kayu manis $500 \mathrm{mg} / \mathrm{kgBB}$. Perbesaran: 100x. Keterangan: a. Hepatosit normal b. Inti hepatosit c. Hepatosit binukleat d. Degenerasi parenkim e. degenerasi lemak

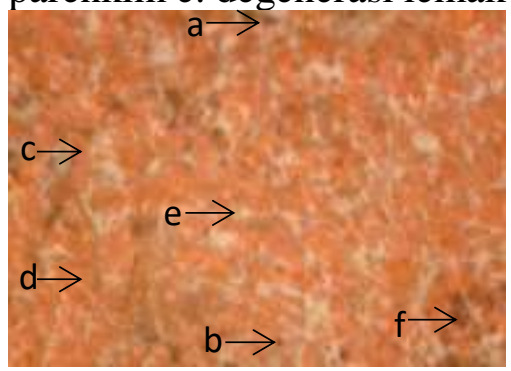

Gambar 4. Pemberian ektrak etanol daun kayu manis 1000 mg/ kgBB. Perbesaran: 100x. Keterangan: a. Hepatosit normal b. Inti hepatosit c. Hepatosit binukleat d. Degenerasi hidropik e. Degenerasi lemak f.

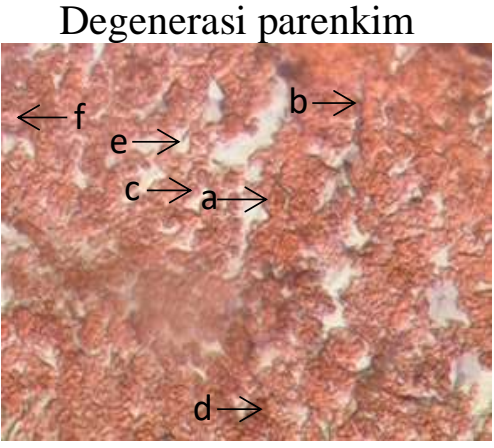

Gambar 5. Pemberian ekstrak etanol daun kayu manis 2000 mg/ kgBB. (Perbesaran: 100x. Keterangan: a. Hepatosit normal b. Inti hepatosit c. Hepatosit binukleat d. Degenerasi parenkim e. Degenerasi lemak f. Degenerasi hidropik). 
Jurnal Ilmiah Ibnu Sina, 6(2), Oktober 2021, 272-281

p-ISSN: 2502-647X; e-ISSN: 2503-1902

Ekstrak etanol $2000 \mathrm{mg} / \mathrm{kgBB}$ menunjukkan terjadinya degenerasi parenkim yang banyak, sel binukleat yang tidak dapat diamati secara jelas membran sel hepatosit serta terjadi degenerasi lemak yang luas, sulit diamati hepatosit normal. Sel yang cedera kemudian bisa mengalami robekan membran plasma dan perubahan inti sel sehingga sel mati atau nekrosis.

Sejalan dengan gambaran hasil pengamatan dimana ditemukan perubahan histopatologi disebabkan berbedanya perlakuan dosis ekstrak yang diberikan pada hewan uji. Namun, dapat diatasi dengan istirahat yang cukup serta pengaturan makanan seimbang (Danastri, 2013).

\section{KESIMPULAN}

1. Kategori toksisitas dari ekstrak daun kayu manis (Cinnamomum burmanii) terhadap mencit putih (Mus musculus L.) betina tergolong kategori praktis tidak toksik karena mempunyai LD > $15 \mathrm{~g} / \mathrm{KgBB}$.

2. Nilai SGPT dan SGOT pada hewan uji mencit putih betina menunjukkan adanya perbedaan nilai SGPT dan SGOT yang bermakna $(p<0,05)$ dibandingkan dengan kontrol negatif namun masih berada pada rentang normal.

3. Terjadi perubahan histopatologi organ hati dibandingkan dengan kontrol negatif.

\section{DAFTAR PUSTAKA}

Abrori C, Nurfadhila K, Sakinah EN. 2019. Uji toksisitas akut ekstrak etanol daun kemangi (Ocimumsanctum) diukur dari nilai $\mathrm{ld}_{50}$ dan histopatologi ginjal. J Agromedicine Med Sci. 5. 1. Hal 13-19.

Adani MF, Sitasiwi AJ, Isdadiyanto S. 2017. Efek antifertilitas ekstrak biji pepaya (Carica Papaya L.) dengan pelarut air terhadap bobot anak mencit (Mus Musculus L.). Buletin Anatomi Dan Fisiologi. 2. 1. Hal 6-11.

BPOM. 2014. Peraturan kepala badan pengawas obat dan makanan republik indonesia nomor 7 tahun 2014 tentang pedoman uji toksisitas nonklinik secara in vivo.

Danastri C. 2013. Sirosis hepatitis pasien dengan riwayat mengkonsumsi alkohol kronik. J Kesehatan. 1. 5. Hal 19-26.

Hasana AN, Sitasiwi AJ, Isdadiyanto S. 2019. Hepatosomatik indeks dan diameter hepatosit mencit (Mus musculus L.) betina 
Jurnal Ilmiah Ibnu Sina, 6(2), Oktober 2021, 272-281

p-ISSN: 2502-647X; e-ISSN: 2503-1902

setelah paparan ekstrak etanol daun mimba (Azadirachta indica Juss.). Pro-Life. 6. 1.

Jumain J, Syahruni S, Farid F. 2018. Uji toksisitas akut dan $\operatorname{ld}_{50}$ ekstrak etanol daun kirinyuh (Euphatorium odoratum Linn) pada mencit (Mus musculus). Media Farmasi. 14. 1. Hal 6572.

Kondoy S, Wullur A, Bodhi W. 2013. Potensi ekstrak etanol daun kayu manis (Cinnamomum burmanii) terhadap penurunan kadar glukosa darah dari tikus putih jantan (rattus norvegicus) yang diinduksi sukrosa, Pharmacon J Ilm Farm, 2,3.

Makiyah A, Tresnayanti S. 2017. Uji toksisitas akut yang diukur dengan penentuan $\mathrm{ld}_{50}$ ekstrak etanol umbi iles-iles (Amorphophallus variabilis Bl.) pada tikus putih strain wistar. Majalah Kedokteran Bandung. 49. 3. Hal 145-155.

Nugraha AS, Hadi NS, Siwi SU. 2012. Efek hepatoprotektif ekstrak buah merah (Pandanus conoideus Lam.) pada hati mencit jantan galur swiss induksi dengan ccl4. J Natur Indones. 11. 1. Hal 24.

OECD. 2001. Guidelines for the testing of chemicals. Oecd.

Priyanto. 2010. Toksikologi Edisi 2. Lenskonfi Lembaga Studi dan Konsultasi Farmakologi, Depok.

Qomar MS, Budiyanto MAK, Sukarsono S, Wahyuni S, Husamah H. 2018. Efektivitas berbagai konsentrasi ekstrak daun kayu manis (Cinnamomum burmannii [ness.] bi) terhadap diameter zona hambat pertumbuhan bakteri Staphylococcus epidermidis. J Biota. 4. 1. Hal 12-17.

Rahayu L, Yantih N, Supomo Y. 2018. Analisis SGOT dan SGPT pada tikus yang diinduksi isoniazid untuk penentuan dosis dan karakteristik hepatoprotektif air buah nanas (Ananas comosus L. Merr) mentah. J Ilmu Kefarmasian Indonesia, 16. Hal 100-106.

Rolini F, Setiawati M, Jusadi D. 2015. Evaluasi pemberian ekstrak daun kayu manis (Cinnamomum burmannii) pada pakan terhadap kinerja pertumbuhan ikan patin Pangasianodon

hypophthalamus Sauvage, 1878. Jurnal Iktiologi

Utomo Y, Hidayat A, Dafip M, Sasi FA. 2012. Studi histopatologi hati mencit (Mus musculus L.) yang diinduksi pemanis buatan. J MIPA Unnes. 32. 2. Hal 122129.

Wulandari TRI, Harini M, Listyawati S. 2007. Pengaruh pemberian ekstrak daun sambiloto (Andrographis paniculata) terhadap Struktur mikroanatomi hepar dan kadar glutamat piruvat transaminase serum mencit (Mus musculus) yang terpapar diazinon. Bioteknologi.4. 2. Hal 53-58. 